\title{
SCGEモデルを用いた大規模洪水の 経済被害推計
}

\section{$\operatorname{AUTHOR}(\mathrm{S})$ :}

鎌谷, 崇史; 中尾, 聡史; 片山, 慎太朗; 東, 徹; 戸田, 祐 嗣; 藤井, 聡

\section{CITATION:}

鎌谷, 崇史 ...[et al]. SCGEモデルを用いた大規模洪水の経済被害推計.土 木学会論文集F4（建設マネジメント） 2018,74(2):I_192-I_201

\section{ISSUE DATE:}

2018

URL:

http://hdl.handle.net/2433/244826

\section{RIGHT:}

(C) 2018 公益社団法人土木学会; 許諾条件に基づいて掲載しています。 


\title{
SCGE モデルを用いた 大規模洪水の経済被害推計
}

\author{
鎌谷 崇史 1 -中尾 聡史 $2 \cdot$ 片山 慎太朗 3 \\ 東 徹 $4 \cdot$ 一田 祐嗣 $5 \cdot$ 藤井 聡 6 \\ 1,2 学生会員 京都大学大学院 工学研究科（广615-8530 京都府京都市西京区京都大学桂 4 C1-2-437) \\ E-mail: ${ }^{1}$ kamatani.t@trans.kuciv.kyoto-u.ac.jp 2 nakao@trans.kuciv.kyoto-u.ac.jp \\ 3,4正会員一般社団法人 システム科学研究所（广 604-8223 京都市中京区新町通四条上ル小結棚町 428） \\ E-mail: ${ }^{3}$ katayama@issr-kyoto.or.jp ${ }^{4}$ higashi@issr-kyoto.or.jp \\ 5 正会員 名古屋大学大学院 工学研究科 ( \\ E-mail: ${ }^{5}$ ytoda@cc.nagoya-u.ac.jp \\ 6 正会員 京都大学大学院 工学研究科（开615-8530 京都府京都市西京区京都大学桂 4 C1-2-437) \\ E-mail: ${ }^{6}$ fujii@ trans.kuciv.kyoto-u.ac.jp
}

我が国では，自然災害に見舞われるリスクが高く，自然現象がもたらす被害を如何に抑制するかが問わ れてきた。 自然災害の中でも, 南海トラフ巨大地震や首都直下型地震による被害については, 近年, 様々 に予測されているが, その一方で, 大規模洪水がもたらす被害, 特に経済被害については, 定量的な予測 が十分になされていない状況である。そこで，本研究では，SCGE モデル（空間的応用一般均衡モデル） を用いた大規模洪水による経済被害の推計手法を考案し, 東京・大阪・東海の 3 つの地域における洪水シ ナリオに基づいて経済被害の推計を行うことを目的とした。

Key Words: Large-scale flood, Resilience, Economic loss, SCGE model

\section{1. はじめに}

我が国では，自然災害に見舞われるリスクが高く，自 然現象がもたらす被害を如何に抑制するかが問われてき た. 自然災害は被災地内の深刻な人的・物的被害を引き 起こすのみならず，国家や社会・経済の機能に致命的な 障害をもたらす危険性があり，このような事態を防ぐ心゙ く, 近年 “Resilient=強勒” な国土ならびに経済社会シ ステムの実現が重要であるとされている.

この考えに基づき，日本政府は 2013 年に「強くしな やかな国民生活の実現を図るための防災・減災に資する 国土強勒化基本法」を成立させ，内閣官房に「国土強勒 化推進室」を設置, 国土強勒化（ナショナル・レジリエ ンス）の基本目標として，いかなる災害が発生しようと も，(1)人命の保護が最大限図られること，(2)国家及び社 会の重要な機能が致命的な障害を受けず維持されること, (3)国民の財産及び公共施設に係る被害の最小化，(4)迅速 な復旧復興，を掲げている ${ }^{1)}$.

この国土強勒化を推進していく上で重要となるのが, 事業の妥当性や緊急性の判断であり, そのためには, 自
然災害によってどれ程の被害が生じるのかといった定量 的な予測が必要とされる. 自然災害の中でも, 特に, 国 難をもたらしか福ない南海トラフ巨大地震や首都直下型 地震による被害については，予測され，公表されている 例えば2), 3).

また，近年，時間雨量が $50 \mathrm{~mm}$ を上回る豪雨が全国的 に増加し，洪水が起こるリスクが高まっていることから， 大規模洪水による経済被害についての被害予測もなされ てきている. 平成 29 年に取りまとめられた「浸水被害 防止に向けた取組事例集」4)では，東京・名古屋・大阪 の三大都市圈における洪水による被害予測が記述されて おり, 浸水面積, 浸水区域内人口, 死者数, 孤立者など の人的被害や, 電力, ガス, 鉄道といったインフラ・ラ イフラインの破断による被害についての想定がなされて いる. 特に, 名古屋については, 治水経済調査マニュア ル ケ基づき，洪水による被害額が約 20 兆円と予測さ れており，その内訳は，直接被害が約 18.3 兆円，間接 被害が約 0.9 兆円となっているの.

直接被害とは, 経済が保有している社会資本, 生産設 備，住宅などの害物資産の被害すなわちストックの被害 
のことであるが 7)，この名古屋における洪水の直接被害 でも，一般資産被害，農作物被害，公共土木施設などの 被害が計上されている。一方，間接被害とは，決まった 概念が存在していないものの，基本的には災害に起因す るフローの被害のことであり 》，この名古屋における洪 水の間接被害には, 事業所などの営業停止被害や応急対 策費用が計上されている. しかし，交通途絶やライフラ イン破断，営業停止による空間的な波及被害については 計上されておらず，十分なフローの被害，すなわち経済 被害については検討されていないと言える. また，洪水 の経済被害の予測を行った既往研究として, 野崎 ${ }^{8) や 小 ~}$ 林 9の研究が挙げられるが, 対象地域をそれぞれ岐阜県 大垣市，兵庫県佐用町に限定した研究となっており，空 間的な波及被害は検討されていない。

そこで，本研究では，SCGE モデル（空間的応用一般 均衡モデル）を用いて，東京・大阪・東海の 3 つのエリ アにおける大規模洪水シナリオでのフロー被害，すなわ ち経済被害の推計を行うことを目的とする.

SCGE モデルは, 地域間の相互依存関係をモデル化し ているため, 被害の発生地域への影響だけではなく, 周 辺地域や全国などへの空間的な被害も捉えることが可能 となる. 本研究では, 各地域での営業停止, 寸なわち, 浸水地域における事業所の生産の停止・停滞による波及 被害について，上記の 3 つのエリアでの大規模洪水シナ リオを想定し，分析をおこなう.

近年, 時間雨量が $50 \mathrm{~mm}$ を上回る豪雨が全国的に増加 し, 洪水が起こるリスクが高まっていることを考慮する と, 大規模洪水による経済被害についての定量的・客観 的知見を供することは，今後実施すべき強勒化政策の妥 当性や緊急性の判断に資するものであると考えられる.

\section{2. 経済被害の推計手法}

本研究では, 浸水世帯数, 浸水面積といった洪水被害 想定から推定される生産資本の被害状況を SCGE モデル (空間的応用一般均衡モデル) に入力することにより， 大規模洪水による経済被害の推計を行うものである。そ こで，(1)では SCGE モデルについて，(2)ではモデルの 前提条件について，(3)では生産資本の被害状況につい て説明する.

\section{(1) SCGE モデル}

本研究では, 小池ら 10)で構築された SCGEモデルを用 いて検討を行う．モデルの定式化については以下に示す 通りである.

\section{a) モデルの概略}

本研究での SCGE モデルでは，まず複数の空間に分割
された社会経済を想定し，それぞれの空間にはアクティ ビティベースの企業および代表的消費者が存在し，それ ぞれ費用最小化行動および効用最大化行動を想定する. 市場に関しては，財，資本は全地域に開放されており， 労働市場は地域内で閉じているものと仮定する. 各市場 においては, 完全競争を仮定し, 財の輸送に関しては, Ice-berg 型輸送技術を想定する。モデルの概略は図-1に 示寸通りである.

なお，本モデルでは，以下のサフィックスで変数を表 すものとする.

・地域を表すサフィックス：

$$
I \in\{1,2, \cdots, i, \cdots, j, \cdots, o, \cdots, I\}
$$

・産業を表すサフィックス：

$$
M \in\{1,2, \cdots, m, \cdots, n, \cdots, M\}
$$

\section{b）企業の行動モデル}

地域 地域で生産された中間投入財, 本源的生産要素（労働・ 資本）により構成される生産要素を用いて，財を生産す る.

各地域には，生産財ごとに 1 つ企業が存在すること

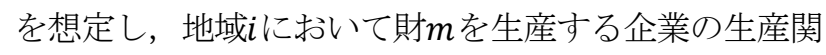
数を Leontief型で仮定すると以下のようになる.

$$
\begin{aligned}
& Y_{i}^{m}=\min .\left\{\frac{v_{i}^{m}}{a_{i}^{0 m}}, \frac{x_{i}^{1 m}}{a_{i}^{1 m}}, \ldots, \frac{x_{i}^{n m}}{a_{i}^{n m}}, \ldots, \frac{x_{i}^{N m}}{a_{j}^{N m}}\right\} \\
& Y_{i}^{m} \quad: \text { 地域 } i \text { の財 } m \text { の生産量 } \\
& v_{i}^{m} \quad: \text { 地域 } i \text { の財 } m \text { の付加価值 } \\
& x_{i}^{n m}: \text { 地域 } i \text { 産業 } n \text { からm } m \text { へ中間投入財 } \\
& a_{i}^{n m} \text { : 地域 } i \text { 産業 } n \text { から } m \text { への中間投入財の投入係数 } \\
& a_{i}^{0 m}: \text { 地域 } i \text { の財 } m \text { の付加価值比率 }
\end{aligned}
$$

次に, 企業の付加価值に関する最適化問題は, 付加価 值 1 単位当たりの要素費用最小化行動として以下のよう に定式化する. ここで付加価值関数は, 労働と資本につ いて規模に関して収穫一定を仮定したコブ・ダグラス型 を仮定する.

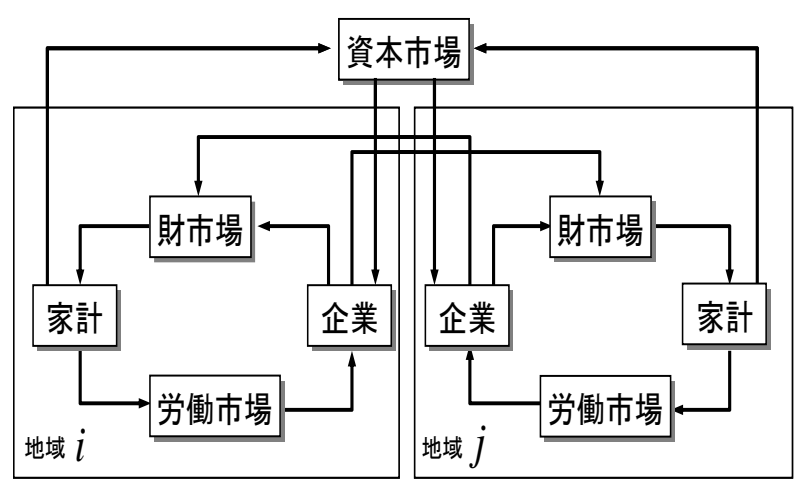

図-1ＳCGEモデルの概略 


$$
\begin{gathered}
\min . w_{i} L_{i}^{m}+r_{i} K_{i}^{m} \\
\text { s.t. } v_{i}^{m}=A_{i}^{m}\left(L_{i}^{m}\right)^{\alpha_{i}^{m}}\left(K_{i}^{m}\right)^{1-\alpha_{i}^{m}}
\end{gathered}
$$

$w_{i} \quad$ : 地域 $i$ 労働賃金率

$\mathrm{r}$ : 資本レント

$L_{i}^{m} \quad:$ 地域 $i$ 財 $m$ の労㗢投入量

$K_{i}^{m} \quad:$ 地域 $i$ 財 $m$ の資本投入量

$\alpha_{i}^{m} \quad$ : 地域 $i$ 財 $m$ の生産要素 (労㗢) の分配パラメータ

$A_{i}^{m} \quad$ : 地域 $i$ 財 $m$ の効率パラメータ (全要素生産性)

式（2）の費用最小化問題をラグランジュ未定乗数法 により解くと, 生産要素需要関数 (労働・資本) が求ま る. また, 付加価值関数が超過利潤ゼロの条件から, 平 均費用として求めることができる.

$$
\begin{aligned}
& L_{i}^{m}=\frac{\alpha_{i}^{m}}{w_{i}} a_{i}^{0 m} q_{i}^{m} Y_{i}^{m} \\
& K_{i}^{m}=\frac{1-\alpha_{i}^{m}}{r} a_{i}^{0 m} q_{i}^{m} Y_{i}^{m} \\
& c v_{i}^{m}=\frac{a_{i}^{0 m} w_{i}^{\alpha_{i}^{m}} r^{1-\alpha_{i}^{m}}}{A_{i}^{m}\left(\alpha_{i}^{m}\right)^{\alpha_{i}^{m}}\left(1-\alpha_{i}^{m}\right)^{1-\alpha_{i}^{m}}}
\end{aligned}
$$

$c v_{i}^{m} \quad:$ 地域 $i U_{才} m$ 単位生産当たりの付加価値

\section{c） 世帯の行動モデル}

各地域には代表的な世帯が存在し，自己の効用が最大 になるように自地域と他地域からの財を消費寸ると仮定 する. すなわち，世帯がどの地域からどれだけ財を消費 するかを地域間交易モデル（Logit モデル）で表現する.

世帯の行動は，以下のような所得制約条件下での効用 最大化問題として定式化する.

$\max . U_{i}\left(d_{i}^{1}, d_{i}^{2}, \ldots, d_{i}^{M}\right)=\sum_{m \in M} \beta^{m} \ln d_{i}^{m}$

$$
\text { s.t. } \overline{l_{l}} w_{i}+r \frac{\bar{K}}{T}=\sum_{m \in M} p_{i}^{m} d_{i}^{m}
$$

$U_{i} \quad$ : 地域 $i$ 効用関数

$d_{i}^{m} \quad$ : 地域 $i$ 財 $m$ の消費水準

$p_{i}^{m} \quad$ : 地域 $i$ 財 $m$ の消費者価格 (C.I.F.PRICE)

$\beta^{m} \quad:$ 財 $m$ の消費の分配パラメータ $\left(\sum_{m \in M} \beta^{m}=1\right)$

$\overline{l_{l}}$ : 地域 $i$ の 1 人当り労働投入量 $\left(\bar{l}_{i}=\sum_{m \in M} L_{i}^{m} / N_{i}\right)$

$\bar{K} \quad$ : 地域全体における総資本保有量

$T$ : 地域全体における総人口 $\left(T=\sum_{i \in I} N_{i}\right)$

式（6）の効用最適化問題をラグランジュ未定乗数法 により解くと，消費財の需要関数を求めることができる.

$$
d_{i}^{m}=\beta^{m} \frac{1}{p_{i}^{m}}\left(\bar{l}_{i} w_{i}+r \frac{\bar{K}}{T}\right)
$$

\section{d）地域間交易モデル}

Harker ${ }^{11)}$ に基づき, 各地域の需要者は消費者価格 （C.I.F.PRICE）が最小となるような生産地の組み合わせ
を購入先として選択する．地域 $j$ に住む需要者が生産地 iを購入先として選択し，その誤差項がガンベル分布に 従うと仮定すると，その選択確率は以下のようなロジッ 卜型の交易モデルで表現できる，なお，本モデルでは， 最終需要量と中間投入需要量を分類し, 各財の消費先選 択確率を明示したモデルを想定するため，消費先選択確 率を最終消費財と中間投入財の 2 パターンで定義する. ただし，実証分析においては，最終消費財と中間投入財 の流動を分別することができないため，式（8）で示す 通り，同一の消費先選択確率を用いる.

$$
F s_{i j}^{m}=I s_{i j}^{m}=\frac{Y_{i}^{m} \exp \left[-\lambda_{o}^{m} q_{i}^{m}\left(1+\psi_{o}^{m} t_{i j}\right)\right]}{\sum_{k \in I} Y_{k}^{m} \exp \left[-\lambda_{o}^{m} q_{k}^{m}\left(1+\psi_{o}^{m} t_{k j}\right)\right]}
$$

$F s_{i j}^{m} \quad$ : 地域 $j$ が地域 $i$ から最終消費財 $m$ を購入する選択確率

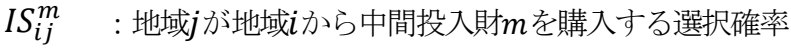
$Y_{i}^{m} \quad:$ 地域 $i$ 財 $m$ の生産量

$t_{i j}$ : 地域 $i か ら$ 地域 $j$ の所要時間（交通抵抗）

$\lambda_{o}^{m} \quad$ : 地域oのロジットモデルのパラメータ

$\psi_{o}^{m} \quad$ : 地域oの価格に占める輸送比率

消費者価格（C.I.F.PRICE）は，生産者価格 （F.O.B.PRICE）に交通抵抗を考慮することで，式（9) のように表わすことができる，大規模災害時は，交通網 の寸断による交通抵抗の増加が想定されるため, この交 通抵抗の増加を政策変数とする既往研究 ${ }^{12}$ もある．ただ し，本研究では，洪水被害を想定するため，地震被害よ りも被災エリアが局所的であり，本研究で想定するゾー ニング(生活圈) 間の所要時間への影響は比較的小さい こと，また浸水による交通寸断の復旧も比較的早いと想 定し, 交通抵抗の変化は考慮しないものとした.

$$
p_{j}^{m}=\sum_{i \in I} F s_{i j}^{m} q_{i}^{m}\left(1+\psi_{o}^{m} t_{i j}\right)
$$

\section{e）市場均衡条件}

本モデルでは，以下の市場均衡条件が成立する。 需要 (最終消費財)

$$
\begin{aligned}
& F z_{i j}^{m}=N_{j} d_{j}^{m} F s_{i j}^{m} \\
& F Y_{i}^{m}=\sum_{j \in J}\left(1+\psi_{o}^{m}\right) F z_{i j}^{m}
\end{aligned}
$$

$F z_{i j}^{m}:$ 財 $m$ の地域 $i$ から地域 $j$ 最終需要流動量

需要（中間投入財 $)$

$$
\begin{gathered}
{\left[\begin{array}{c}
I X_{i}^{1} \\
\vdots \\
I X_{i}^{m} \\
\vdots \\
I X_{i}^{M}
\end{array}\right]=\left[\begin{array}{ccc}
1-a_{i}^{11} & \cdots & 0-a_{i}^{1 N} \\
\vdots & \ddots & \vdots \\
0-a_{i}^{M 1} & \cdots & 1-a_{i}^{M N}
\end{array}\right]^{-1}\left[\begin{array}{c}
F Y_{i}^{1} \\
\vdots \\
F Y_{i}^{m} \\
\vdots \\
F Y_{i}^{M}
\end{array}\right]} \\
I Z_{i j}^{m}=I X_{j}^{m} \times I s_{i j}^{m} \\
I X_{j}^{m} \quad: \text { 地域 } j \text { 財 } m \text { の中間投入需要量 } \\
I z_{i j}^{m} \quad: \text { 財 } m \text { の地域 } i \text { から地域 } j \text { の中間投入需要流動量 }
\end{gathered}
$$


供給

$$
\begin{aligned}
Y_{i}^{m}=\sum_{j \in J}\left(1+\psi_{o}^{m}\right. & \left.t_{i j}\right) F z_{i j}^{m} \\
& +\sum_{j \in J}\left(1+\psi_{o}^{m} t_{i j}\right) I z_{i j}^{m}
\end{aligned}
$$

本源的生産要素

$$
\begin{gathered}
\sum_{m \in M} L_{i}^{m}=\bar{L}_{\imath} \\
\sum_{i \in I} \sum_{m \in M} K_{i}^{m}=\bar{K}
\end{gathered}
$$

生産者価格体系

$$
\begin{gathered}
q_{j}^{n}=a_{j}^{0 n} c v_{j}^{n}+\sum_{m \in M} a_{j}^{m n} \sum_{i \in I} I s_{i j}^{m} q_{i}^{m}\left(1+\psi_{o}^{m} t_{i j}\right) \\
q_{j}^{n} \quad: \text { 地域 } j \text { 財 } n \text { の生産者価格 (F.O.B.PRICE) }
\end{gathered}
$$

\section{(2) モデルの前提条件}

\section{a) 対象範囲とゾーニング}

SCGE モデルの分析対象範囲については, 明確な設定 基準はないが，社会資本整備による影響が及ぶ範囲，即 ち，現況での経済的取引が多いエリアを網羅的に設定す ることが望ましいと考えられる，本研究ではそれぞれの 大規模洪水のシナリオにおいて浸水が想定される生活圈 を対象とする．また，ゾーニングは，全国幹線旅客純流 動調査で設定されている207生活圈とする.

\section{b) 経済データ}

これまで設定した前提条件を基に，SCGE モデルにイ ンプットする経済データを作成する. SCGE モデルで通 常使用される経済データは, 地域間産業連関表であり, 基準均衡状態が再現されたデータであるため, 各パラメ 一夕（中間投入財の投入係数・付加価值比率等）も地域 間産業連関表より算出することが可能である. 一方，本 研究で想定する生活圈のように, 都道府県レベルよりも 小規模な地域レベルでの産業連関表は政府統計として整 備されていないため, 他の統計デー夕等を活用し, 基準 均衡データとする必要がある.

そこで, 本研究では, 都道府県民経済計算, 都道府県 単位の産業連関表や物流データを代用することで, 生活 圈レベルでの基準均衡データを作成した. 具体の手順は, 以下に示す通りである.

まず，付加価值額については，都道府県民経済計算の 付加価値額を使用する. 都道府県民経済計算は, 各都道 府県で整備されており, 市町村単位での付加価值額を把 握することが可能であることから，本研究では，都道府 県民経済計算の地域別データを集約することで，各生活 圈の付加価值額を作成した.ただし，公表されている都 道府県民経済計算では，製造業を細分化したデータは公
表されていないため, 公表値をコントロールトータルと し, 工業統計調査を活用することで，表-1 で示す 16 分 類でデータ按分した.

次に, 地域の技術構造を示寸投入係数 $a_{i}^{n m}$ は, 産業連 関表より得られるパラメータであるため, 産業連関表が 整備されていない生活圈レベルで得ることはできない. そこで, 本研究では, 各都道府県で整備されている産業 連関表を用い，同一の都道府県下の生活圏においては， 共通の投入係数で代用することとした. この投入係数と 式（8）の地域間選択確率より, 各生活圈の財別の中間 投入需要量を式（13）から得ることができる. 同様に, 消費の分配パラメータ $\beta^{m}$ も, 各都道府県で整備されて いる産業連関表の数值で代用し, 最終需要項目の基準均 衡データとした.

以上の算出方法およびデータ出典については，表-2 で示す通りである. なお，生活圈別の労働所得および資 本所得については, 整理した各生活圈の付加価值額を, 都道府県別産業連関表の付加価值項目を構成する労働所 得項目と資本所得項目のシェアで按分することで作成し た. なお，労働所得項目と資本所得項目の分類について

\begin{tabular}{|c|c|}
\hline $\begin{array}{c}\text { 産業活動 } \\
\text { 関連データ }\end{array}$ & 算出方法および出典 \\
\hline 付加価値額 & • H17 都道府県民経済計算 \\
\hline 人口 & •H17 国勢調査 \\
\hline 労働所得 & $\begin{array}{l}\text { • 生活圈別付加価值額 } \times \text { 労働シェア※ } \\
※ \text { ※付加価值額のうち, 家計外消費支出+雇 } \\
\text { 用者所得+間接税 }+ \text { (控除) 経常補助金 }\end{array}$ \\
\hline 資本所得 & $\begin{array}{l}\text { • 生活圈別付加価值額 } \times \text { 資本シェア※ } \\
\text { ※付加価値額のうち, 営業余剰 + 資本減耗 } \\
\text { 引当 }\end{array}$ \\
\hline 中間投入係数 & • H17 産業連関表（都道府県別） \\
\hline 消費のシェア & • H17 産業連関表（都道府県別） \\
\hline
\end{tabular}
は, 明確に示されてはいないが，本研究では，小池ら ${ }^{13)}$ で示された分類方法に従うものとした.

表-1 産業分類

\begin{tabular}{r|l|r|l}
\hline No. & \multicolumn{1}{|c|}{ 産業名 } & No. & \multicolumn{1}{c}{ 産業名 } \\
\hline \hline 1 & 農林水産業 & 9 & 鉄鋼・非鉄金属・金属製品 \\
2 & 鉱業 & 10 & 一般機械 \\
\hline 3 & 飲食料品 & 11 & 電気機械・情報・通信機器 \\
\hline 4 & 繊維製品 & 12 & 輸送機械 \\
\hline 5 & パルプ・紙・木製品 & 13 & その他の製造工業製品 \\
\hline 6 & 化学製品 & 14 & 建設 \\
\hline 7 & 石油・石炭製品 & 15 & 電力・ガス・水道 \\
\hline 8 & 窯業・土石製品 & 16 & サービス \\
\hline
\end{tabular}

表-2 インプットデータの概説 


\section{（3）地域間交易モデルのパラメータ設定}

式（8）で示したロジットモデルでは，未知パラメー タが 2つあることから，他のパラメータ推定時に使用し たキャリブレーションで推定することはできない，そこ で，本研究では，グリッドサーチによって交易モデルの パラメータを推定した. グリッドサーチは，推定值と実 測值の誤差二乗和が最小となるようなパラメータの組合 せを求める手法であり，例えば小池ら ${ }^{14} の$ 研究において 用いられている，本研究では，実測值に国土交通省総合 政策局より公表されている全国貨物純流動調查（物流セ ンサス）15を活用し，地域ブロック別にパラメータ推定 をおこなった，推定結果は，図-2, 図-3に示寸通りであ る. ただし, 建設, 電力・ガス・水道, サービスについ ては，地域間交易のデータが整備されていないことから， 本研究では地域内交易のみとし, 地域間交易はおこなわ ないものとした.

\section{（4）現況再現性}

被災前の状況下での計算結果 $\left(G R P_{\text {(before })}\right)$ と, 作 成した実測值 (GRP) を使い，現況再現性の確認をおこ なった．結果は，図-4 に示通りであり，産業別で見 た場合でも，良好な結果が得られていると考えられる。

\section{(5) 生産資本の被害状況}

次に, SCGE モデルに入力する生産資本の被害状況の 推定手法について述べる.

はじめに，東京・大阪・東海の 3 つの地域における洪 水シナリオに基づく洪水被害想定（浸水世帯数）より, 各生活圈の浸水比を式(18)により算出する（洪水シナリ オについては後述する）。

$R_{i} \quad$ : 生活圈 $\mathrm{i}$ の浸水比

$$
R_{i}=K_{2 i} / K_{1 i}
$$

$K_{1 i} \quad$ : 生活圈 $\mathrm{i}$ の総世帯数

$K_{2 i} \quad$ : 生活圈 $\mathrm{i}$ の浸水世帯数

ただし，東京の洪水シナリオについては世帯数のデー タが得られなかったため, 生活圈ごとの総面積と浸水面 積によって浸水比を算出した. そして, この浸水比によ って各生活圈の生産資本が毁損すると仮定した.

しかし，これらの生産資本が毀損しているのはあくま で初期時点でのことであり，そこから徐々に回復してい く，その回復の度合いについては，大原ら ${ }^{10 か ゙ ， イ ン タ ~}$ ビューを通して 2015 年 9 月の関東・東北豪雨災害に伴 う鬼怒川堤防の決壊による茨城県常総市内の事業所の被 災特性をインタビュー調査している。 この調査では, 鬼 怒川東側にある被災事業所 55 社を対象として, 事業所 の災害状況や売り上げの回復状況を尋衫ており, その研 究成果を踏まえて, 洪水の発生から 14 ケ月目に全回復 寸ると想定した（55 社の事業所の産業分類は，D（建設
業) , E (製造業) , F（電気・ガス・熱供給・水道 業）, $\mathrm{H}$ (運輸業）, I（卸売業・小売業）, J (金融 業），K（不動産業・物品賃貸業），L（専門・技術业 一ビス業），M（宿泊業・飲食サービス業），N（生産 関連サービス業)， R（サービス業）になっており，大

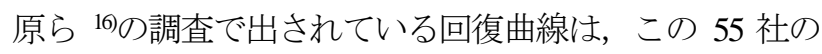
平均となっている）.

さらに, 生産資本が回復したとしても, それが直ちに 売上額ひいては経済全体の回復につながるわけではない. 実際，大原ら ${ }^{10}$ によれば，洪水発生から５ケ月目に職場 の環境はおよそ 50\%回復したのに対し，売上額がその水 準まで回復するのは 13 ケ月を要した, となっている. そこで本研究の計算では, 生産資本と売上額の被害の時 間積分の比を補正係数として生産資本毀損に乗じること によって経済全体の被害を求めることとする．大原ら ${ }^{10}$ の研究では, 売上額の回復曲線の 50\%以上の值について 得られていなかったため, 今回の分析では 50\%回復にか かった期間をもとに，図-5 の三角形 ABD と三角形 $\mathrm{ACD}$ の面積比である $\alpha=2.6$ を補正係数として採用している. 以上を踏まえ, 生産資本の毀損による経済被害は以下の ように推計される.

まず，浸水後の事業所の稼動割合を式(19)により計算 寸る．なお “平均稼動事業所割合” は前述した回復曲線 の想定のもと, 洪水発生 14 ケ月目までの各月の稼動事 業所割合（職場の環境が回復した事業所の割合）の平均 值とした. 式（19）で得られた生活圈別の生産資本毀損 量を被災シナリオとし，毁損した生産資本量分を SCGE モデルのインプットデータである付加価值（労働所得・ 資本所得）の直接的な減少量と想定し, 計算をおこなっ た.

$$
M_{i(\text { damaged })}=M_{i(\text { before })} \times R_{i} \times(1-P A)
$$

$M_{i(\text { damaged }) ~}$ : 生活圈 $\mathrm{i}$ 生産資本毀損量

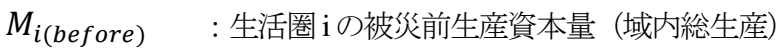

PA : 平均稼動事業所割合 (0.5036199)

上記のシナリオに基づき，被災前後の GRP を SCGE モデルで計算し，その差分を経済被害額とする．SCGE モデルでは, 財および生産要素の均衡状態を想定してい るため，被災からある程度の期間が経過した安定状態を 仮定している.この安定した状態は, 災害の規模, 種類, 発生した地域によって異なるが，より被害が長期化する 場合は人口移動等も含めた動学モデルにより検討され， 生産要素市場も全地域で解放されていると想定される. 一方, 本研究では静学的な SCGEモデルを想定しており, 生産要素市場のうち労働市場は地域内で閉じていると仮 定していることから, 数年単位の長期間に渡り顕在化す る被害影響までは考慮されていない，そのため，SCGE モデルで算出される GRP が概ね年単位であると想定し, また生産資本の毀損に基づいて行われていることから， 


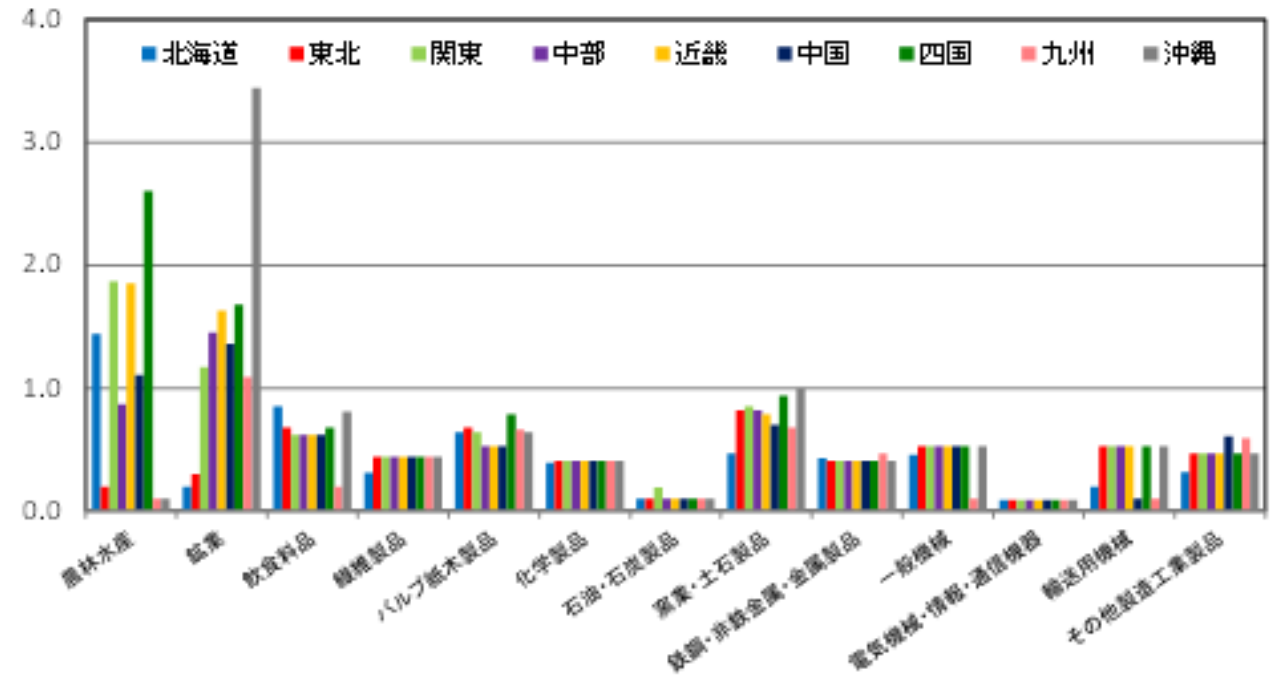

図-2 地域間交易モデルのパラメータ $\left(\lambda_{o}^{m}\right)$ 推定結果

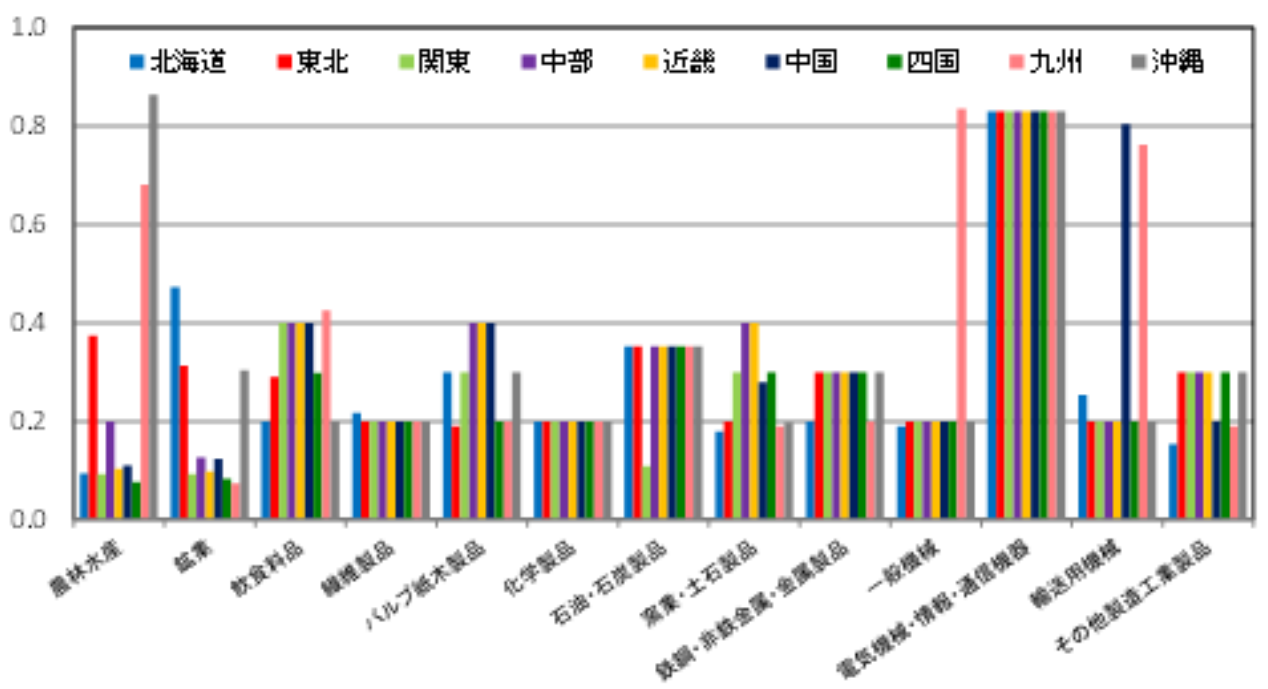

図-3 地域間交易モデルのパラメータ $\left(\psi_{o}^{m}\right)$ 推定結果

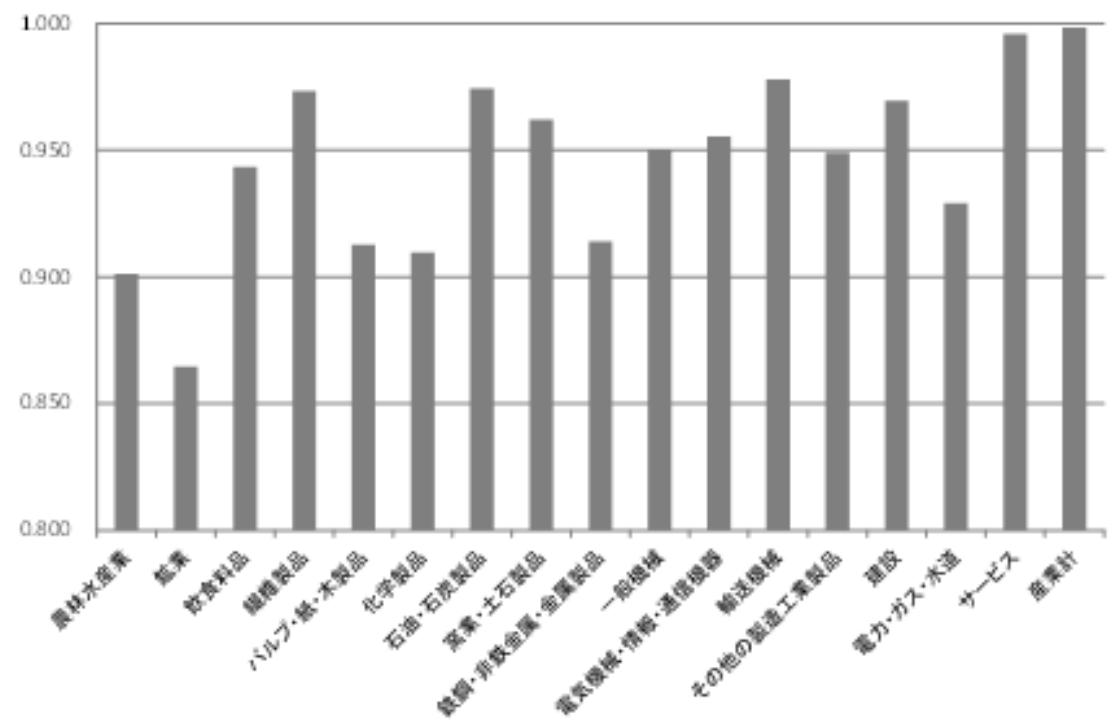

図-4 現況再現性（相関係数） 


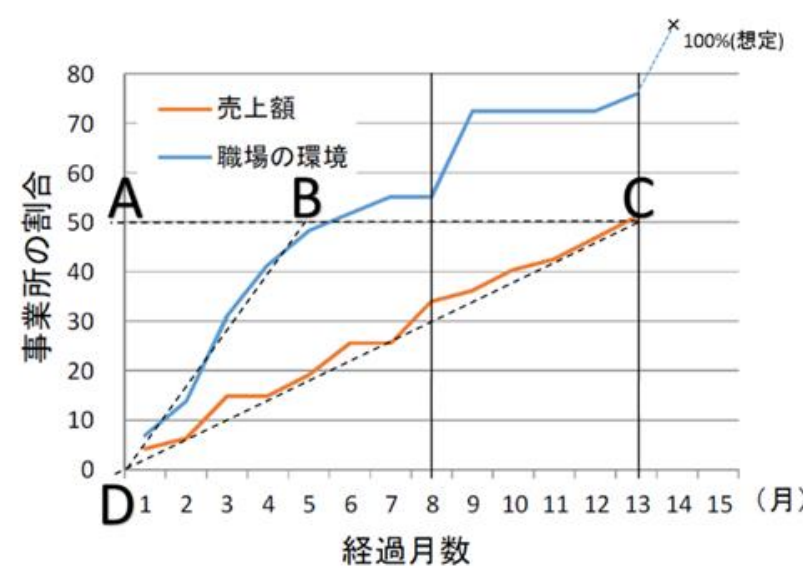

図-5 売上額及ひ職場環境の回復曲線

(大原ら ${ }^{16)}$ より作成)

経済全体の回復にはさらに長期間を要すると考えられる ため，大規模洪水による経済被害を式(20)により算出す る.

なお，災害からの復興期間については，明確な定義が 難しいため, 災害の規模, 種類, 発生した地域によって どの程度異なるのか等，さらなる実態調査や研究の蓄積 が必要である.また，災害からの復興には，もちろん， 復興のための投資が必要であり，多々納・高木 ${ }^{17}$ が指摘 するように，復興のための投資額もまた経済被害として

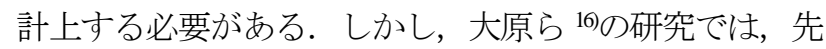
述したように，全回復するまでの回復曲線が得られてお らず，途中の復興（回復）までの投資額について検討さ れていないため, 本研究においても, 復興のための投資 額については, 分析の対象外とした.

$$
\begin{aligned}
G R P_{(\text {damaged })}= & \left(G R P_{i(\text { before })}-G R P_{i(\text { after })}\right) \\
& \times \frac{14}{12} \times \alpha
\end{aligned}
$$

$$
\begin{aligned}
& G \mathrm{R} P_{(\text {damaged })} \text { : 大規模洪水による経济被害額 }
\end{aligned}
$$

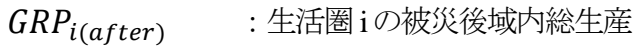

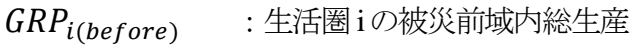

$$
\begin{aligned}
& \alpha \quad \text { : 補正係数 (2.6) }
\end{aligned}
$$

\section{3. 推定結果}

本研究では内閣府中央防災会議ならびに国土交通省関 東・中部・近畿地方整備局の想定する洪水シナリオのう ち，とりわけ甚大な被害が想定される「荒川洪水（東京） 18)」「淀川洪水（大阪） ${ }^{19}$ 」「庄内川等洪水（東海）。」 について経済被害の推計を行った．各シナリオの詳細を 表-3 に記す．また，これらの洪水シナリオに基づく， 浸水世帯数, 浸水面積といった洪水被害想定の值につい ては国土交通省水管理・国土保全局から提供いただいた。 各シナリオの経済被害の推計結果を表-4に記す.

推計結果であるが，東京 $21.0 \mathrm{k}$ シナリオ，大阪 $9.2 \mathrm{k} シ$
ナリオ，東海シナリオ，東海（対策あり）シナリオにお いて，洪水による経済被害（GDP 毀損）が，それぞれ 29.4 兆円，8.1 兆円，14.7 兆円，4.8 兆円生じることが推 計された。

東京都心部が浸水する可能性があるとされる東京 21.0k シナリオにおいて，今回の分析中最も大きな額と なる経済被害が推計された。企業活動等の経済機能が過 度に集中している首都圈においては，同規模の洪水によ る経済被害が他地域にくらべ深刻化することが考えられ る.

大阪 9.2k シナリオ，東海シナリオの被害についても， 東京には及ばないものの甚大な経済被害であることが分 かる，東海エリアにおいては，庄内川の氾濫による名古 屋生活圈での被害が大きく, 庄内川の堤防対策を施した 場合（東海（対策あり）シナリオの場合），経済被害は 14.7 兆円から 4.8 兆円の約 3 分の 1 に抑えられるという 推計結果が得られた。

また，被災地域以外一の空間的な被害状況を見ると， 東京 $21.0 \mathrm{k}$ シナリオでは，被災地域外では約 3.0 兆円 （総被害額に対して 10\%程度）であるのに対して，大阪 9.2k シナリオでは約 1.2 兆円（総被害額に対して約 14\%），東海シナリオでは約 2.5 兆円（総被害額に対し て約 17\%）となっており，被害の総額では東京 $21.0 \mathrm{k}$ シ ナリオが最も大きくなっているが，他地域一の影響度合 いで見ると，東海シナリオが大きくなっていることが分 かる。東海地域は，地理的にも東京と大阪の中間に位置 しており，トヨタをはじめとしたモノづくり産業が集積 している地域であることから，企業の操業停止およびサ プライチェーン寸断による影響が全国へ波及し，その被 害影響が広範にわたることが本研究の結果から示唆され

\begin{tabular}{|c|c|c|}
\hline シナリオ & 詳細 & 被災生活圈 \\
\hline 東京 $21.0 \mathrm{k}^{18}$ & $\begin{array}{l}\text { 荒川右岸 } 21.0 \mathrm{~km} \text { 地点に } \\
\text { て堤防が決壊. }\end{array}$ & $\begin{array}{c}\text { 浦和・川越 } \\
23 \text { 区 }\end{array}$ \\
\hline 大阪 $9.2 \mathrm{k}^{19)}$ & $\begin{array}{l}\text { 淀川左岸 } 9.2 \mathrm{~km} \text { 地点にて } \\
\text { 堤防が決壊. }\end{array}$ & 大阪 \\
\hline 東海の) & $\begin{array}{l}\text { 揖斐川右岸 } 27.2 \mathrm{~km} \text { 地 } \\
\text { 点, 長良川右岸 } 19.0 \mathrm{~km} \\
\text { 地点, 木曾川左 岸 } \\
21.8 \mathrm{~km} \text { 地点, 庄内川左 } \\
\text { 岸 } 17.2 \mathrm{~km} \text { 地点にて堤防 } \\
\text { が決壊. }\end{array}$ & $\begin{array}{c}\text { 岐阜・大垣 } \\
\text { 名古屋・豊田 } \\
\text { 北勢 }\end{array}$ \\
\hline $\begin{array}{c}\text { 東海 } \\
\text { (対策あり) }\end{array}$ & $\begin{array}{l}\text { 庄内川は堤防決壊せ } \\
\text { ず, 揖斐川, 長良川, } \\
\text { 木曽川では上記「東 } \\
\text { 海」のケースと同じ箇 } \\
\text { 所で決壊. }\end{array}$ & $\begin{array}{l}\text { 岐阜・大垣 } \\
\text { 豊田・北勢 }\end{array}$ \\
\hline
\end{tabular}
る.

表-3＼cjkstart洪水シナリオ

注） 全てのシナリオにおいて，想定最大規模の降雨による 巨大洪水を想定外力としている. 
表-4 大規模洪水による経済被害推計結果（MおよびGRPの単位は“億円”）

\begin{tabular}{|c|c|c|c|c|c|c|}
\hline \multicolumn{7}{|c|}{ 東京 21.0k シナリオ } \\
\hline 被災エリア & $K_{1}\left(\mathrm{~km}^{2}\right)$ & $K_{2}\left(\mathrm{~km}^{2}\right)$ & $\mathrm{R}$ & $M_{(\text {before })}$ & $M_{(\text {damaged })}$ & $G R P_{(\text {damaged })}$ \\
\hline 浦和 & 1,199 & 47 & 0.03947467 & 115,369 & 2,261 & 15,843 \\
\hline 川越 & 1,144 & 1 & 0.0012677 & 64,796 & 41 & 971 \\
\hline 23 区 & 618 & 49 & 0.07963571 & 808,944 & 31,977 & 247,507 \\
\hline 被災地域以外 & - & - & 0 & $4,234,028$ & 0 & 29,533 \\
\hline & & & & & 合計 & 293,854 \\
\hline
\end{tabular}

\begin{tabular}{|l|r|r|r|r|r|r|}
\hline \multicolumn{1}{|c|}{ 大阪 9.2k シナリオ } \\
\hline 被災エリア & \multicolumn{1}{|c|}{$K_{1}($ 戸) } & \multicolumn{1}{|c|}{$K_{2}($ 戸) } & \multicolumn{1}{c|}{$\mathrm{R}$} & $M_{(\text {before })}$ & $M_{(\text {damaged })}$ & $G_{(\text {damaged })}$ \\
\hline 大阪 & $1,314,544$ & 148,658 & 0.11308677 & 182,011 & 10,217 & 69,409 \\
被災地域以外 & - & - & 0 & $5,041,126$ & 0 & 11,505 \\
\hline
\end{tabular}

\begin{tabular}{|c|c|c|c|c|c|c|}
\hline \multicolumn{7}{|c|}{ 東海 シナリオ } \\
\hline 被災エリア & $K_{1}$ (戸) & $K_{2}($ 戸 $)$ & $\mathrm{R}$ & $M_{(\text {before })}$ & $M_{(\text {damaged })}$ & $G R P_{(\text {damaged })}$ \\
\hline 岐阜 & 349,177 & 68 & 0.00019474 & 34,652 & 3 & 409 \\
\hline 大垣 & 128,884 & 7,198 & 0.05584867 & 14,254 & 395 & 2,740 \\
\hline 名古屋 & $1,021,227$ & 240,750 & 0.23574582 & 115,509 & 13,517 & 83,986 \\
\hline 豊田 & $1,635,562$ & 81,203 & 0.04964838 & 204,292 & 5,035 & 34,626 \\
\hline 北勢 & 315,986 & 143 & 0.00045255 & 40,441 & 9 & 644 \\
\hline 被災地域以外 & - & - & 0 & $4,813,989$ & 0 & 24,822 \\
\hline & & & & & 合計 & 147,226 \\
\hline
\end{tabular}

\begin{tabular}{|l|r|r|r|r|r|r|}
\hline \multicolumn{7}{|c|}{ 東海 (対策あり) シナリオ } \\
\hline \multicolumn{1}{|c|}{ 被災エリア } & \multicolumn{1}{|c|}{$K_{1}($ 戸) } & \multicolumn{1}{c|}{$K_{2}($ 戸) } & \multicolumn{1}{c|}{$\mathrm{R}$} & $M_{\text {(before })}$ & $M_{\text {(damaged })}$ & $G_{\text {(damaged })}$ \\
\hline 岐阜 & 349,177 & 68 & 0.00019474 & 34,652 & 3 & 216 \\
\hline 大垣 & 128,884 & 7,198 & 0.05584867 & 14,254 & 395 & 2,637 \\
豊田 & $1,635,562$ & 81,184 & 0.04963676 & 204,292 & 5,033 & 33,176 \\
\hline 北勢 & 315,986 & 143 & 0.00045255 & 40,441 & 9 & 392 \\
被災地域以外 & - & - & 0 & $4,929,498$ & 0 & 11,852 \\
\hline
\end{tabular}

\section{4. まとめ}

本研究では，SCGE モデル（空間的応用一般均衡モデ ル）を用いた大規模洪水による経済被害の推計手法を考 案し，東京・大阪・東海の 3 つのエリアにおける洪水シ ナリオに基づいて経済被害の推計を行った.

その結果，東京都心部が浸水する可能性があるとされ る東京 21.0k シナリオにおいて，今回行った分析の中で, 最も大きな額となる 29.4 兆円の経済被害が推計された. また，大阪 9.2k シナリオにおいて 8.1 兆円，東海シナリ オにおいて 14.7 兆円の経済被害が生じるという推計結 果が得られた。一方，被災地以外の他地域への被害状況 を見ると, 総被害に対する割合が東海シナリオで最も大 きくなっており，サプライチェーン寸断等による広範囲 での被害波及が懸念されることが明らかとなった。この
ような空間的影響の違いは，地域間の産業連関構造を表 現した SCGEモデルを用いることで事前に把握すること ができ，既存の治水経済調査マニュアル 5に基づく評価 手法では把握できない事項である.さらに，東海におい ては庄内川の氾濫による名古屋生活圏での被害が大きく， 庄内川の堤防対策により，経済被害は 14.7 兆円から 4.8 兆円の約 3 分の 1 に抑えられるという推計結果が得られ, その効果は非常に大きいことが本研究から確認すること ができた.

本研究で得られた推計結果は, 洪水による経済被害, すなわちフローの被害が甚大なものであること，そして， 洪水被害を防ぐための防災対策の必要性を示すものであ ると考えられる. 近年, 時間雨量が $50 \mathrm{~mm}$ を上回る豪雨 が全国的に増加し，洪水が起こるリスクが高まっている ことを考慮すると，こうした分析は，今後実施すべき強 
勒化政策の妥当性や喫緊性の判断に資するものであると 考えられる.

なお，今後の課題については以下の通りである.まず, 本研究では，2015年 9 月の関東・東北豪雨災害に伴う鬼 怒川堤防の決壊による茨城県常総市内の事業所の被災特 性に基づいた推計であるが，被災による影響は，災害の 規模，種類，発生した地域によって異なると想定される. 特に，長期にわたり被害が顕在化する災害を想定する場 合，それに応じたモデルの改良，およびインプットとな る政策シナリオも検討する必要がある. そのためにも， 各災害での被害の違いなど, さらなる害態調査や研究の 蓄積が必要であると考えられる，また，本研究では，大 原ら ${ }^{10 の}$ の研究に基づき, 洪水被害の推計を行ったため, 生産額の回復曲線が 50\%までしが得られておらず，より 正確な分析を行うには，100\%に至るまでの回復曲線を 調査する必要がある，産業分類についても，本研究では, 産業分類を行わずに 55 社の平均值から回復曲線を求め ているが，産業ごとに回復曲線を導出することも今後の 課題として挙げられる. 他にも, 本研究で推計した経済 被害には，復興のための投資額について考慮しておらず， こうした点も今後は検討していく必要があろう.

さらに, 本研究では, 東京・大阪・東海の 3 つの地域 における洪水シナリオに基づいて経済被害の推計を行っ たが，本研究で考案した経済被害の推計手法を用いて， 他のエリアにおいても洪水による経済被害の予測を行っ ていく必要がある.

謝辞 : 洪水の被害想定に当たり，国土交通省水管理・国 土保全局よりデータを提供いただきました。 ここに記し て謝意を表します。

\section{参考文献}

1) 国土強勒化推進室: 国土強勒化とは?, 2014.

2) 内閣府（防災担当）：南海トラフ巨大地震の被害想 定（第二次報告）のポイント〜施設等の被害及び経 済的な被害〜, 2013.

3) 中央防災会議首都直下地震対策検討ワーキンググル ープ: 首都直下地震の被害想定と対策について（最 終報告）, 2013.

4）国土交通省：浸水被害防止に向けた取組事例集〜社会 経済被害の最小化の実現に向けて,2017.

http://www.mlit.go.jp/river/bousai/shinsuihigai/index.htm 1

5）国土交通省河川局：治水経済調查マニュアル,2005.. http://www.mlit.go.jp/river/basic_info/seisaku_hyouka/ga iyou/hyouka/h1704/chisui.pdf

6) 東海ネーデルランド高潮・洪水地域対策協議会 : TNT 大規模水害対策レポート 01 社会経済の壊滅的 被害回避方策, 2017.

7) 永松伸吾・林敏彦：間接被害概念を用いた復興政策 評価指標の開発，地域安全学会梗概集 No.13.pp.89-
90, 2003

8) 野崎道哉：大垣市における仮想的洪水災害に関する 経済被害の推計, 地域経済, 第 35 集, pp.33-38, 2017.

9) 小林健一郎・寶馨 - 奥勇一郎 : 統合型降雨流出 - 洪 水氾濫モデルによる佐用町洪水災害分析と経済被害 推定, 土木学会論文集 B1, Vol.67, No.4, pp.949-954, 2011.

10) 小池淳司 - 佐藤啓輔 - 片山慎太朗：中間投入構造を 明示した小規模多地域応用一般均衡モデルの構築, 第 53 回土木計画学研究発表会・講演集, pp.12971302, 2016.

11) Harker, P. T. : Predicting Intercity Freight Flows, VNU Science Press BV, 1987.

12）土屋哲・多々納裕一：SCGE モデルを用いた基幹交 通網に関する地震リスクのパブリックマネジメント， 社会技術研究論文集, Vol.2, pp.228-237, 2004.

13）小池淳司・上田孝行・伊藤克彦 : 社会資本ストック 整備効果計測に関する研究-応用一般均衡モデルと生 産関数アプローチによる理論的・実証的比較-, 土木 計画学研究・講演集, Vol.24, 2001.

14）小池淳司・佐藤啓輔・川本信秀：帰着便益分析によ る道路ネットワーク整備の公平性評価-RAEM-Light モデルを用いたアプローチ-, 高速道路と自動車, Vol.51, No.12, pp.27-33, 2008.

15) 国土交通省: 全国貨物純流動調査, http://www.mlit.go.jp/sogoseisaku/transport/butsuryu06100.html

16）大原美保・南雲直子・澤野久弥：平成 27 年 9 月関 東・東北豪雨による常総市内の事業所の被災特性に 関寸る調查研究, 土木学会論文集 B1, Vol.74, No.4, pp.1159-1164, 2018.

17) 多々納裕一・高木朗義：災害リスクマネジメント施 策の経済評価，『防災の経済分析リスクマネジメン 卜の施策と評価』第 4 章, 勁草書房, 2005.

18) 最大規模の洪水等に対応した防災・減災対策検討 会：「社会経済の壊滅的な被害の回避」に向けた取 り組み〜最大クラスの洪水・高潮による被害想定に ついて〜, 2017.

19) 大阪大規模都市水害対策検討会 : 大阪大規模都市水 害対策ガイドライン（中間とりまとめ，第 2 版）, 2017.

(2018.5.21 受付) 
【付表】SCGE モデルの各パラメータの推定式と推定方法

\begin{tabular}{|c|c|c|c|}
\hline & パラメータ & 推定式 & 推定方法 \\
\hline$a_{i}^{n m}$ & 投入係数 & $a_{i}^{n m}=\frac{x_{i}^{n m}}{q_{i}^{m} Y_{i}^{m}}$ & キャリブレーション \\
\hline$a_{i}^{0 m}$ & 付加価值比率 & $a_{i}^{0 m}=\frac{w_{i} L_{i}^{m}+r K_{i}^{m}}{q_{i}^{m} Y_{i}^{m}}$ & キャリブレーション \\
\hline$\alpha_{i}^{m}$ & 分配パラメータ & $\alpha_{i}^{m}=\frac{w_{i} L_{i}^{m}}{w_{i} L_{i}^{m}+r K_{i}^{m}}$ & キャリブレーション \\
\hline$A_{i}^{m}$ & 効率パラメータ & $A_{i}^{m}=\frac{w_{i} L_{i}^{m}+r K_{i}^{m}}{\left(L_{i}^{m}\right)^{\alpha_{i}^{m}}\left(K_{i}^{m}\right)^{1-\alpha_{i}^{m}}}$ & キャリブレーション \\
\hline$\beta^{m}$ & 消費財の分配パラメータ & $\beta^{m}=\frac{p_{i}^{m} d_{i}^{m}}{\sum_{m \in M} p_{i}^{m} d_{i}^{m}}$ & キャリブレーション \\
\hline$\lambda^{m}, \quad \psi^{m}$ & ロジットモデルのパラメータ & $\begin{array}{c}\min . \sum_{j \in J} \sum_{i \in I}\left(s_{i j}^{m}-D_{i j}^{m}\right)^{2} \\
D_{i j}^{m}: \text { 実測值 }\end{array}$ & グリッドサーチ \\
\hline
\end{tabular}

\title{
AN ESTIMATION OF ECONOMIC LOSS DUE TO INUNDATION CAUSED BY LARGE-SCALE FLOODS BY SCGE MODEL
}

\author{
Takeshi KAMATANI, Satoshi NAKAO, Shintaro KATAYAMA \\ Tohru HIGASHI, Yuji TODA, and Satoshi FUJII
}

Japan faces great risk of natural disasters and it is concerned that there will be other large-scale disasters which may cause fatal damage to important functions for maintaining administration as well as social and economic systems. In order to avoid such kind of situations, recently it is said to be important to make resilient national land. However, estimations of damage such as economic loss caused by largescale floods have not been done yet, even though these are quite important to assess the validity of measures to promote National Resilience. Therefore, this study conducted estimations of economic loss due to inundation caused by large-scale floods in Tokyo, Osaka, and Tokai areas according to the expected floods scenarios by a spatial computable general equilibrium (SCGE) model. As a result of that, serious damage to the economy triggered by inundation in Tokyo, Osaka, and Tokai areas was estimated. The result suggests the great need of mitigation measures against large-scale floods. 